\title{
Strafrecht
}

\section{Zorgen om de rechtsstaat in Polen bij uitvoering van een Europees aanhoudingsbevel}

\author{
Prof. mr. P.A.M. Verrest*
}

Het Hof van Justitie heeft in een arrest van 17 december 2020 prejudiciële vragen beantwoord van de rechtbank Amsterdam. De rechtbank wilde weten of de aantasting van de onafhankelijkheid van de rechtspraak in Polen betekent dat de overlevering van personen aan die lidstaat op grond van een Europees aanhoudingsbevel dient te worden geweigerd, ook zonder de concrete omstandigheden in de desbetreffende zaak aan een gedetailleerd onderzoek te onderwerpen. Het Hof van Justitie herhaalt dat de dreiging van een mensenrechtenschending voor de opgeëiste persoon altijd moet worden beoordeeld op het niveau van de individuele zaak. Er is bovendien geen reden om een Poolse rechter niet langer als 'rechterlijke autoriteit' in de zin van het kaderbesluit Europees aanhoudingsbevel aan te merken.

Hv7 17 december 2020, gevoegde zaken C-354/20 PPU en C-412/20 PPU, ECLI:EU:C:2020:1033 (L. en P.).

\section{Inleiding}

Op 17 december 2020 heeft het Hof van Justitie uitspraak gedaan in twee gevoegde zaken waarin prejudiciële vragen waren gesteld door de Internationale rechtshulpkamer van de rechtbank Amsterdam. ${ }^{1}$ In die zaken moest de rechtbank Amsterdam oordelen over de uitvoering van een door de Poolse autoriteiten uitgevaardigd Europees aanhoudingsbevel (EAB). Kortgezegd wilde de rechtbank Amsterdam weten of de aantasting van de onafhankelijkheid van de rechtspraak in Polen aanleiding zou moeten geven om de uitvoering van EAB's afkomstig van Poolse rechters te weigeren

Prof. mr. P.A.M. (Pieter) Verrest is hoogleraar straf(proces)recht, in het bijzonder Europees en Internationaal strafrecht, aan Erasmus School of Law te Rotterdam.

1. Rb. Amsterdam 31 juli 2020, ECLI:NL:RBAMS:2020:3776 en Rb. Amsterdam 3 september 2020, ECLI:NL:RBAMS:2020:4328. wegens een reëel gevaar op schending van het recht op een eerlijk proces van de opgeëiste persoon.

De uitspraak van het Hof van Justitie is in verschillende opzichten van belang. Allereerst biedt de uitspraak verdere verduidelijking over de wijze waarop de overleveringsrechter volgens het Hof van Justitie het gevaar van een mensenrechtenschending moet beoordelen en onderzoeken. Het Hof van Justitie gaat ook in op de vraag of de eisen die moeten worden gesteld aan de onafhankelijkheid van de autoriteit die een EAB uitvaardigt, een rol kunnen spelen. In dit arrest komen voor het eerst de verschillende lijnen bij elkaar die het Hof van Justitie hieromtrent eerder heeft uitgezet in zijn rechtspraak over het kaderbesluit Europees aanhoudingsbevel (kaderbesluit EAB).

Daarbij is het arrest van belang in het kader van wat inmiddels een groot probleem is geworden voor de Europese Unie: de schaamteloze aantasting door de Poolse regering van de onafhankelijkheid van de rechtspraak in die lidstaat. De Europese Unie worstelt met de vraag hoe aan de elkaar in rap tempo opvolgende schendingen een einde kan worden gemaakt.

Het gaat het bestek van deze bijdrage te buiten om de situatie in Polen uitvoerig te beschrijven. ${ }^{2}$ Heel in het kort snoerde de Poolse regering van de conservatieve PiS-partij in 2016 eerst het Constitutionele Hof de mond door de voorzitter te vervangen door een regeringsgezinde magistraat. Vervolgens werd in 2017 een nauwelijks verhulde poging ondernomen om met een abrupte verlaging van de pensioenleeftijd een groot aantal rechters van het Poolse Hooggerechtshof naar huis te sturen. Zo zou de regering verlost zijn van actieve toetsing van haar wetgeving en beleid. Een interventie van de Europese Commissie via het Hof van Justitie droeg eraan bij dat deze maatregel uiteindelijk werd teruggedraaid. Vervolgens heeft de Poolse regering bij het

2. Voor nadere uitleg van de situatie in Polen kan o.a. worden verwezen naar J. Morijn, 'De EU en de rechtsstatelijke crises in Hongarije en Polen; urgentie vergt (gedifferentieerde) actie', NJB 2021/203. 
Hooggerechtshof een nieuwe Tuchtkamer voor de rechtspraak ingesteld. De leden van die Tuchtkamer zijn niet op onafhankelijke wijze benoemd. ${ }^{3}$ De Tuchtkamer heeft het gemunt op kritische rechters. Op basis van de zogenoemde muilkorfwet, aangenomen in 2019 en in werking getreden in februari 2020, is het voor rechters verboden om de onafhankelijkheid van de Tuchtkamer te betwisten en zich te bemoeien met het beleid van de regering. Dit heeft in de praktijk ook tot gevolg dat het stellen van prejudiciële vragen over de onafhankelijkheid van de rechtspraak in Polen en het uitvoering geven aan uitspraken van het Hof van Justitie over de Tuchtkamer verboden is. De situatie waarin de Poolse rechtspraak verkeert, wordt nauwlettend gevolgd door rechters in andere lidstaten, die zich solidair tonen met hun Poolse collega's. Zo werd in januari 2020 in Warschau als protest tegen de aantasting van de onafhankelijkheid van de rechtspraak in Polen, de 'Mars van de duizend toga's' georganiseerd, waaraan ook rechters uit andere lidstaten deelnamen, waaronder Nederland. ${ }^{4}$ De Europese Commissie is vanwege de aantastingen van de onafhankelijkheid van de rechtspraak eind 2017 de speciale procedure gestart tegen Polen die artikel 7 lid 1 Verdrag betreffende de Europese Unie (VEU) voorziet wegens schending van de waarden van de Unie (het zogenoemde Rule of Law-mechanisme). ${ }^{5}$ De Poolse regering staat echter binnen de Europese Raad niet alleen omdat zij kan rekenen op de steun van de Hongaarse regering. Zo kan Polen voorkomen dat de procedure tot sancties zal leiden, omdat daarvoor unanimiteit van de (andere) lidstaten nodig is. In december 2020 heeft de Europese Raad besloten om een nieuw mechanisme in stelling te brengen: aan de meerjarenbegroting van de EU zou voortaan een nieuwe rechtsstaattoets moeten worden gekoppeld. Lidstaten die de beginselen van de democratische rechtsstaat schenden, zouden kunnen worden gekort op EU-subsidies. ${ }^{6} \mathrm{Zo}$ ver is het voorlopig nog niet: Polen en Hongarije zijn tegen het besluit om de rechtsstaattoets in te voeren in beroep gegaan bij het Hof van Justitie en in de Europese Raad is afgesproken dat op de uitkomst van die procedure wordt gewacht. ${ }^{7}$

Het Hof van Justitie is op deze en andere wijzen betrokken geraakt bij de problemen met de onafhankelijkheid van de rechtspraak in Polen. De Europese Commissie is een aantal inbreukprocedures gestart tegen Polen bij het Hof van Justitie wegens schendingen van de rechtsstaat

3. Zie Aanbeveling (EU) $2018 / 103$ van de Europese Commissie van 20 december 2017 over de rechtsstaat in Polen ter aanvulling van de Aanbevelingen (EU) 2016/1374, (EU) 2017/146 en (EU) 2017/1520.

4. R. van der Kroft, 'De mars van de duizend toga's', Advocatenblad (online) 22 januari 2020

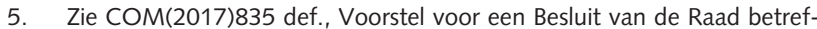
fende de constatering van een duidelijk gevaar voor een ernstige schending, door de Republiek Polen, van de rechtsstaat, gebaseerd op art. 7 lid 1 VEU.

6. Verordening (EU) 2020/2092 van het Europees Parlement en de Raad van 16 december 2020 betreffende een algemeen conditionaliteitsregime ter bescherming van de Uniebegroting (PbEU 2020, L 433/1).

7. Zie 'Fonds européens et Etat de droit: la Pologne et la Hongrie saisissent la Cour de justice de l'UE', Le Monde 12 maart 2021
- over de onafhankelijkheid van het Hooggerechtshof, ${ }^{8}$ de onafhankelijkheid van de rechtspraak en de instelling van de Tuchtkamer. ${ }^{9}$ In alle zaken waarin het Hof van Justitie tot dusver uitspraak heeft gedaan heeft dit tot een veroordeling van de maatregelen van de Poolse regering geleid. Recent heeft de Europese Commissie een nieuwe zaak aangespannen tegen Polen wegens (het niet intrekken van) de muilkorfwet. ${ }^{10}$ Tevens hebben Poolse rechters prejudiciële vragen gesteld over de onafhankelijkheid van de Tuchtkamer en het op hen van toepassing zijnde disciplinaire regime. ${ }^{11}$ Ten slotte heeft de aantasting van de rechterlijke onafhankelijkheid in Polen mogelijk gevolgen voor de strafrechtelijke samenwerking tussen EU-lidstaten en Polen. Ook daarover zijn prejudiciële vragen gesteld aan het Hof van Justitie: in het besproken arrest door de rechtbank Amsterdam en eerder door een Ierse rechter in de zogenoemde zaak $L M .^{12}$ Het gaat dan over de gevolgen die de aantasting van de onafhankelijkheid van de rechtspraak zou moeten hebben voor de overlevering van gezochte personen aan Polen.

\section{De strafrechtelijke}

\section{samenwerking tussen lidstaten voor overlevering van personen}

De Europese Unie is een ruimte van vrijheid, veiligheid en recht. Dit betekent onder andere dat er op intensieve wijze wordt samengewerkt tussen de lidstaten bij de bestrijding van criminaliteit. Dat kan op basis van een hoge mate van onderling vertrouwen tussen de lidstaten. Die samenwerking is in de sleutel geplaatst van wederzijdse erkenning. Het bekendste voorbeeld daarvan is het kaderbesluit $\mathrm{EAB}^{13}$ voor de overlevering van gezochte personen tussen EU-lidstaten. Van zuivere wederzijdse erkenning ${ }^{14}$ is daarbij geen sprake: het is niet zo dat een anhoudingsbevel van een Italiaanse rechter rechtstreeks wordt uitgevoerd door de politie in Rotterdam. Een beslissing van de rechterlijke autoriteiten van de uitvaardigende lidstaat wordt eerst door de rechterlijke autoriteiten van de uitvoerende lidstaat beoordeeld. Daarbij wordt getoetst aan een aantal voorwaarden en weigeringsgronden. De meest prominente (maar zelden toegepaste) weigeringsgrond is die van een

8. HvJ 17 december 2018, zaak C-619/18, ECLI:EU:C:2018:1021 (Europese Commissie/Polen) en HvJ 24 juni 2019, ECLI:EU:C:2019:531 (Europese Commissie/Polen).

9. HvJ 8 april 2020, zaak C-791/19, ECLI:EU:C:2020:277 (Europese Commissie/Polen).

10. 'Europese Commissie daagt Polen voor Europese Hof van Justitie vanwege rechtspraak', NRC Handelsblad 31 maart 2021.

11. HvJ 19 november 2019, gevoegde zaken C-585/18, C-624/18 en C-625/18, ECLI:EU:C:2019:982 (A. K.); HvJ 26 maart 2020, gevoegde zaken C-558/18 en C-563/18, ECLI:EU:C:2020:234; HvJ 2 maart 2021, zaak C-824/18, ECLI:EU:C:2021:153 (A.B. e.a.).

12. HvJ 25 juli 2018, zaak C-216/18 PPU, ECLI:EU:C:2018:586 (LM).

13. Kaderbesluit $2002 / 584 / J B Z$.

14. Vgl. de strafrechtelijke samenwerking tussen landen van het Koninkrijk op basis van het Statuut voor het Koninkrijk. 
reëel gevaar van schending van mensenrechten in de uitvaardigende lidstaat. Die weigeringsgrond wordt afgeleid uit artikel 1 lid 3 kaderbesluit EAB. Dat bepaalt dat 'het kaderbesluit niet tot gevolg [kan] hebben dat de verplichting tot eerbiedigen van de grondrechten en de fundamentele rechtsbeginselen, zoals die zijn neergelegd in artikel $6 \mathrm{VEU}$, wordt angetast'. Dit betekent dat - in analogie met de verplichtingen die voortvloeien uit artikel 1 Europees Verdrag tot bescherming van de rechten van de mens en de fundamentele vrijheden (EVRM) de rechter die komt te oordelen over het toestaan van de overlevering van een opgeëiste persoon, in geval van een reëel gevaar voor een schending van de fundamentele rechten van de opgeëiste persoon na overlevering, de uitvoering van het $\mathrm{EAB}$ moet opschorten of zelfs weigeren.

In de praktijk van de strafrechtelijke samenwerking tussen lidstaten bestaat bij rechters met enige regelmaat twijfel over de (mensenrechten)situatie waarin een opgeëiste persoon na overlevering aan de uitvaardigende lidstaten terechtkomt. ${ }^{15}$ De Unie heeft het nodige gedaan om dat te verbeteren, bijvoorbeeld door regelgeving over verstekvonnissen ${ }^{16}$ aan te nemen en regelgeving ter bevordering van alternatieven voor voorlopige hechtenis waarmee kan worden voorkomen dat een opgeëiste persoon na overlevering lange tijd in een buitenlandse gevangenis moet wachten op behandeling van zijn zaak. ${ }^{17}$ Nog belangrijker is dat in 2009 de Routekaart procedurele rechten ${ }^{18}$ is aangenomen, met als resultaat de totstandkoming in de jaren erna van een zestal richtlijnen inzake onder meer het recht op informatie, het recht op toegang tot een raadsman en de versterking van het vermoeden van onschuld. Die richtlijnen hebben geleid tot harmonisatie van het strafprocesrecht van de lidstaten waar het gaat om waarborging van een aantal bij de toepassing van het strafrecht aan de orde zijnde fundamentele rechten.

Dit alles neemt niet weg dat de zorgen om de mensenrechtensituatie in een antal lidstaten inmiddels een wissel trekken op de strafrechtelijke samenwerking. Dat geldt in het bijzonder voor de slechte detentieomstandigheden in gevangenissen in een aanzienlijk aantal lidstaten. De zorgen om de onafhankelijkheid van de rechterlijke organisatie in Polen vormen een tweede voorbeeld.

Het zijn dermate ernstige situaties, dat de aandacht van rechters die moeten oordelen over uitvoering van een EAB afkomstig van lidstaten waar deze problemen spelen, zich richt op toepassing van de weigeringsgrond afgeleid uit artikel 1 lid 3 kaderbesluit EAB. Maar wat zijn daarvoor de criteria? Hoe ernstig moet een schen-

15. COM(2005)195. Zie verder o.a. P.A.M. Verrest, Europese idealen, Den Haag: Boom juridisch 2016, p. 15-18.

16. Kaderbesluit $2009 / 299 / J B Z$ tot versterking van de procedurele rechten van personen, tot bevordering van de toepassing van het beginsel van wederzijdse erkenning op beslissingen gegeven ten aanzien van personen die niet verschenen zijn tijdens het proces.

17. Kaderbesluit 2008/829/JBZ inzake toezichtmaatregelen als alternatief voor voorlopige hechtenis. Zie verder o.a. J. Beneder, 'Detentie in de Europese Unie', Sancties 2018/12.

18. Resolutie van de Raad, 2009/C 295/1. ding zijn om tot opschorting of weigering van de uitvoering van een EAB te leiden? Hierover zijn de afgelopen jaren door nationale rechters al meerdere malen prejudiciële vragen gesteld aan het Hof van Justitie.

\section{De toetsing van een dreigende mensenrechtenschending}

De eerste zaken waarin prejudiciële vragen over weigering van de uitvoering van een $\mathrm{EAB}$ werden gesteld aan het Hof van Justitie hadden betrekking op de slechte detentieomstandigheden in lidstaten: wat voor gevolg moest daaraan worden verbonden voor de overlevering van opgeëiste personen aan die lidstaten? Aanleiding was concreet de veroordeling door het Europees Hof voor de Rechten van de Mens (EHRM) van een aantal EU-lidstaten in individuele zaken aangespannen door gedetineerden, omdat detentieomstandigheden dermate slecht waren dat sprake was van een schending van artikel 3 EVRM: vernederende of onmenselijke behandeling. In uitspraken over detentieomstandigheden in Italië, Bulgarije, Hongarije en Roemenië besloot het EHRM tot een pilotprocedure: de schending van mensenrechten werd als systematisch gezien en de desbetreffende lidstaten werd een bepaalde periode de tijd gegeven om verbeteringen in wetgeving en praktijk aan te brengen. ${ }^{19}$ Duitse rechters wilden van het Hof van Justitie weten of zij op grond van de uitspraken van het EHRM de uitvoering van een EAB afkomstig van de betrokken lidstaten zouden moeten weigeren. $\mathrm{Zij}$ wezen daarbij op artikel 4 Handvest van de grondrechten van de Europese Unie (Handvest) (verbod van foltering, onmenselijke of vernederende behandeling; pendant van art. 3 EVRM) waaraan artikel 19 lid 2 Handvest toevoegt dat uitlevering verboden is bij een ernstig risico op foltering, onmenselijke of vernederende behandeling. In de zaak Aranyosi en Caldararu beantwoordde het Hof van Justitie in 2016 de door de Duitse rechter gestelde vragen. ${ }^{20}$ Het Hof van Justitie stelde voorop dat de werking van de beginselen van wederzijdse erkenning en wederzijds vertrouwen tussen lidstaten slechts in uitzonderlijke omstandigheden kan worden beperkt. Wanneer de rechter die beslist over uitvoering van een $\mathrm{EAB}$ wordt geconfronteerd met objectieve, betrouwbare, nauwkeurige en actuele gegevens die duiden op gebreken die hetzij structureel of fundamenteel zijn, hetzij bepaalde groepen van personen raken, hetzij bepaalde detentiecentra betreffen, dient de rechter concreet en nauwkeurig na te gaan of er zwaarwegende en op feiten berustende gronden bestaan om aan te nemen dat de opgeëiste persoon een reëel gevaar loopt op een mensen-

19. Zie o.a. EHRM 10 maart 2015, appl.nr. 14097/12 (Varga e.a./Hongarije) en EHRM 25 april 2017, appl.nr. 61467/12 (Rezmives e.a./Roemenië).

20. HvJ 5 april 2016, gevoegde zaken C-404/15 en C-659/15 PPU, ECLI:EU:C:2016:198 (Aranyosi \& Caldararu). Zie hierover o.a. M.I. Veldt-Foglia, 'Wederzijds vertrouwen in EAB-zaken op de helling? Law in action vs. law in the books', NtEr 2016/8, p. 259-266. 
rechtenschending. Daartoe dient de uitvoerende rechter de uitvaardigende autoriteit te verzoeken om aanvullende informatie, die deze gegevens binnen de door de uitvoerende rechter gestelde termijn dient te verstrekken. De uitvoerende rechter stelt zolang zijn beslissing over de overlevering uit. Indien het bestaan van dit gevaar niet binnen een redelijke termijn kan worden uitgesloten, dient de rechter te beslissen of de overleveringsprocedure moet worden beëindigd. In de praktijk komt dit erop neer dat de overlevering wel enige tijd wordt opgeschort, maar niet wordt geweigerd.

Bij mogelijke mensenrechtenschendingen is er aldus sprake van een toetsing in twee stappen: (1) Is sprake van informatie van structurele of fundamentele gebreken in de bescherming van mensenrechten? En vervolgens (2) Is sprake van een reëel gevaar voor de opgeëiste persoon in de individuele zaak? De beoordeling van deze vragen is de verantwoordelijkheid van de uitvoerende rechter. $^{21}$

\section{De LM-zaak: overlevering en de onafhankelijkheid van de rechtspraak in Polen}

Het Hof van Justitie kreeg in 2018 voor de eerste maal vragen over de mogelijke gevolgen van de aantasting van de onafhankelijkheid van de rechtspraak in Polen voor overleveringszaken.

In deze zaak $L M^{22}$ had een Ierse rechter de vraag gesteld of het in gang zetten van de Rule of Law-procedure van artikel 7 lid 1 VEU door de Europese Commissie tegen Polen wegens schending van de onafhankelijkheid van de rechtspraak, voldoende was om in individuele zaken een schending van artikel 47 Handvest - het recht op een doeltreffende voorziening in rechte en op een onafhankelijke en onpartijdige rechter - aan te nemen. Ingeval er toch een concrete toets diende te worden verricht in de individuele zaak, wilde de verwijzende rechter weten of aanvullende informatie moest worden gevraagd aan de Poolse autoriteiten, en welke waarborgen dan zouden zijn vereist.

Het Hof van Justitie stelde dat wanneer de uitvoerende rechter over gegevens beschikt die erop wijzen dat er een reëel gevaar dreigt dat het recht op een eerlijk

21. In HvJ 25 juli 2018, zaak C-220/18 PPU, ECLI:EU:C:2018:589 (ML) benadrukte het Hof van Justitie vervolgens dat behalve in het verkrijgen van antwoorden op de gestelde vragen eveneens een oplossing kan worden gevonden in het feit dat autoriteiten van de uitvaardigende lidstaat een garantie geven dat de opgeëiste persoon niet onderworpen zal worden aan een onmenselijke of vernederende behandeling. In de praktijk kunnen garanties een oplossing bieden. Zo vraagt de rechtbank Amsterdam bij de uitvoering van Franse EAB's steevast de garantie dat de opgeëiste persoon na overlevering niet gedetineerd wordt in een aantal specifiek genoemde gevangenissen die door het EHRM (o.a. EHRM 30 januari 2020, appl.nr. 9671/15 (J.M.B./Frankrijk) in de ban zijn gedaan wegens slechte detentieomstandigheden: zie o.a. $\mathrm{Rb}$. Amsterdam 3 september 2020, ECLI:NL:RBAMS:2020:5862.

22. HvJ 25 juli 2018, zaak C-216/18 PPU, ECLI:EU:C:2018:586 (LM). proces, zoals gewaarborgd door artikel 47 Handvest, wordt geschonden wegens structurele of fundamentele gebreken met betrekking tot de onafhankelijkheid van de rechterlijke macht van de uitvaardigende lidstaat, die uitvoerende rechter concreet en nauwkeurig moet nagaan of dat in deze concrete zaak inderdaad het geval is. Het gaat dus om dezelfde tweestappentoets als in de zaak Aranyosi, inclusief de verplichting om vragen te gaan stellen aan de uitvaardigende autoriteit.

Het door het Hof van Justitie in de zaak $L M$ neergezette kader wordt in de praktijk door nationale rechters als weinig bevredigend ervaren. ${ }^{23}$ Het Hof van Justitie werpt - zo is de indruk - een hoge drempel op voor de mogelijkheid om de overlevering in een concrete zaak te weigeren wegens een dreigende mensenrechtenschending. De opdracht die het Hof van Justitie geeft om eerst nader onderzoek te verrichten is bovendien voor nationale rechters niet eenvoudig uit te voeren. Ze moeten zelf bepalen wat in dit verband de relevante vragen zijn waarop antwoord dient te komen. In het geval van Polen moet er dan een soort dialoog gevoerd worden met de uitvaardigende rechter over diens eigen onafhankelijkheid en over de positie van de rechtsprekende macht waarvan hij deel uitmaakt; dat is behoorlijk ongemakkelijk. ${ }^{24}$ Onduidelijk is verder wat de vragen stellende rechter moet aanhouden als redelijke termijn waarbinnen de antwoorden mogen worden verlangd en hoe de negatieve consequenties die de langere duur van de zaak heeft voor de opgeëiste persoon, moeten worden gewogen en kunnen worden gecompenseerd. ${ }^{25}$

\section{De eisen te stellen aan een rechterlijke autoriteit in het kaderbesluit EAB}

In een arrest van 27 mei 2019 (OG en PI) (Openbaar ministerie van Lübeck en van Zwickau) adresseerde het Hof van Justitie op een andere wijze het vereiste van onafhankelijkheid van de rechterlijke macht: niet zozeer die van de rechter maar van de officier van justitie. ${ }^{26}$ De positie van de officier van justitie is in de meeste rechtsstelsels met minder waarborgen voor onafhankelijkheid omkleed. In artikel 6 lid 1 kaderbesluit EAB wordt gesteld dat een 'rechterlijke autoriteit' bevoegd is tot uitvaardiging van een EAB. In het kaderbesluit is niet

23. Zie o.a. J.W. Ouwerkerk \& P.J. Slot, 'De Poolse rechtsstaat onder druk: van artikel 7 VEU naar het Europees aanhoudingsbevel en weer terug', AA 2018, p. 1040-1046.

24. E. Filius \& J.W. Ouwerkerk, 'De Poolse rechtsstaat en het Europees aanhoudingsbevel: wie is/zijn er nu aan zet?', Nederlandrechtsstaat.nl 23 december 2020.

25. Zie V. Glerum, 'Reflecties op het arrest LM', NTM/NJCM-Bull. 2020/07, p. $92-93$

26. HvJ 27 mei 2019, gevoegde zaken C-508/18 en C-82/19 PPU, ECLI:EU:C:2019:456 (OG en PI). Zie o.a. de bespreking van S.M.A. Lestrade in EHCR 2019/181 en J.W. van der Hulst, 'De uitleg van het begrip rechterlijke autoriteit bij de uitvaardiging van een Europees arrestatiebevel', NtEr 2019/5-6, p. 158-165. 
gepreciseerd of het alleen om rechters gaat, of ook om officieren van justitie. In de praktijk werd dat laatste aangenomen. Het Hof van Justitie bepaalt in deze zaak nu dat een (Duitse) officier van justitie alleen kan worden aangemerkt als rechterlijke autoriteit in de zin van het kaderbesluit $\mathrm{EAB}$, als hij niet ondergeschikt is aan de uitvoerende macht - bijvoorbeeld door het bestaan van een aanwijzingsbevoegdheid van de minister van Justitie. Het Hof van Justitie stelt dat de procedure die leidt tot uitvaardiging van een EAB dient te zijn onderworpen aan rechterlijk toezicht waarmee de waarborging van de grondrechten van de opgeëiste persoon is verzekerd. Dat kan niet worden bewerkstelligd door een officier van justitie die indirect wordt aangestuurd door of instructies kan ontvangen van de uitvoerende macht. ${ }^{27}$

\section{Het arrest van}

\section{7 december 2020 (L. en $P$.)}

De twee lijnen in de rechtspraak van het Hof van Justitie inzake overlevering, die van het reële gevaar van een mensenrechtenschending en die van de te stellen eisen aan de rechterlijke autoriteit die een EAB uitvaardigt, komen samen in het arrest van 17 december 2020. ${ }^{28}$

De rechtbank Amsterdam heeft in de eerste zaak drie prejudiciële vragen gesteld en in de tweede zaak die prejudiciële vragen angevuld. ${ }^{29}$ Het verschil tussen beide zaken is dat het in de eerste zaak handelt om een vervolgingsoverlevering en het in de tweede gaat om een executieoverlevering. In de zaak van de vervolgingsoverlevering moet het proces van de opgeëiste persoon voor de Poolse rechter nog volgen, in de zaak van de executieoverlevering is de opgeëiste persoon al veroordeeld door de Poolse rechter en gaat het erom of hij in Polen zijn straf zal gaan uitzitten.

De rechtbank leidt haar prejudiciële vragen in door erop te wijzen dat zij teneinde te bepalen of er mogelijk sprake is van een schending van fundamentele rechten in Polen, via het Openbaar Ministerie een aantal vragen aan de Poolse uitvaardigende autoriteit van het EAB heeft gericht. De ontvangen antwoorden vindt de rechtbank onbevredigend en onvolledig. Bovendien is de situatie van de rechtspraak in Polen wederom verslechterd. Daarbij verwijst de rechtbank naar de uitspraken van het Hof van Justitie naar aanleiding van prejudiciële vragen van Poolse rechters over de aantasting van hun

27. Inmiddels is de lijn doorgetrokken ten aanzien van de uitvoerende rechterlijke autoriteit in het kaderbesluit EAB: zie HvJ 24 november 2020, C-510/19. ECLI:EU:C:2020:953

28. HvJ 17 december 2020, gevoegde zaken C-354/20 PPU en C-412/20 PPU, ECLI:EU:C:2020:1033 (L. en P.). Zie ook S.M.A. Lestrade, 'Ondanks aanhoudende rechtsstaatcrisis mogen Poolse EAB's niet structureel worden geweigerd', ECHR Updates 2021-0017.

29. In de tweede zaak gaat het anders dan in de eerste zaak om overlevering ter executie van een reeds door de Poolse rechter opgelegde straf. Bovendien meldt de rechtbank Amsterdam enkele nieuwe ontwikkelingen met betrekking tot de onafhankelijkheid van de rechtspraak in Polen. onafhankelijkheid. Voorts is de eerdergenoemde muilkorfwet aangenomen en in werking getreden. Ten slotte is de Tuchtkamer van het Hooggerechtshof een disciplinaire procedure gestart tegen een als kritisch bekendstaande Poolse rechter (Igor Tuleya) met als doel hem op non-actief te stellen. ${ }^{30}$

De eerste vraag die de rechtbank stelt, bouwt voort op het arrest $O G$ en PI. Komt aan de Poolse rechter die het EAB heeft uitgevaardigd aan Nederland nog wel de kwalificatie 'rechterlijke autoriteit' toe, nu de onafhankelijkheid van de Poolse rechter niet langer is gewaarborgd, omdat die is blootgesteld aan mogelijke disciplinaire maatregelen van de niet-onafhankelijke Tuchtkamer?

Het Hof van Justitie stelt dat het van groot belang is dat een rechterlijke autoriteit op onafhankelijke wijze kan optreden bij de uitvaardiging van een EAB. Maar ook indien de rechter die het $\mathrm{EAB}$ moet uitvoeren over gegevens beschikt waaruit structurele of fundamentele gebreken blijken in de onafhankelijkheid van de rechterlijke macht in de uitvaardigende lidstaat, kan die de rechter in de uitvaardigende lidstaat niet zomaar de hoedanig van rechterlijke autoriteit ontzeggen. Belangrijk is volgens het Hof van Justitie dat het bestaan van dergelijke gebreken niet noodzakelijkerwijs van invloed is op elke beslissing die de rechterlijke instanties van een lidstaat in elk specifiek geval nemen. ${ }^{31}$

Daarbij zou dit er volgens het Hof van Justitie op neerkomen dat een Poolse rechter ook elders in het EUrecht niet meer als rechter zou kunnen worden angemerkt, in het bijzonder waar het gaat om de bevoegdheid om prejudiciële vragen te stellen aan het Hof van Justitie (art. 267 VWEU). ${ }^{32}$ Uit het arrest $O G P I$ volgt dat teneinde te gelden als 'rechterlijke autoriteit' in de zin van het kaderbesluit $\mathrm{EAB}$, er statutaire en organisatorische voorschriften moeten bestaan die waarborgen dat de uitvaardigende rechterlijke autoriteit niet het risico loopt te worden blootgesteld an instructies van de uitvoerende macht. Dat laatste is uitgesloten waar het gaat om rechters, anders zou een orgaan op grond van het Unierecht niet als rechter kunnen worden aangemerkt. Dit betekent dat uit het arrest $O G$ en PI (dat, ter herinnering, zag op de positie van de officier van justitie) niet kan worden afgeleid dat structurele of fundamentele gebreken met betrekking tot de onafhankelijkheid van de rechtspraak, op zichzelf volstaan om een rechter niet aan te merken als 'uitvaardigende rechterlijke autoriteit'. ${ }^{33}$

In de tweede vraag stelt de rechtbank Amsterdam dat er sprake is van zodanige structurele en fundamentele gebreken met betrekking tot de onafhankelijkheid van de Poolse rechtspraak, dat voor niemand die moet verschijnen voor een Poolse rechter het recht op een onafhankelijke rechter is gewaarborgd. Moet dan nog wel de tweede stap worden gezet, zoals het Hof van Justitie

\footnotetext{
30. L. en P., punt 13-15.

31. L. en $P$., punt 42 .

32. L. en $P$., punt 44.

33. L. en $P$., punt $48-50$.
} 
heeft voorgeschreven in het Aranyosi-arrest en heeft herhaald in de $L M$-zaak? Dat lijkt volgens de rechtbank niet nodig.

In de derde vraag geeft de rechtbank Amsterdam aan dat zij meent over voldoende feitelijke informatie te beschikken die wijst op een aantasting van de onafhankelijkheid van de rechtspraak in Polen, notabene door zaken van de Poolse Tuchtkamer. Is dat niet voldoende om een reëel gevaar van schending van het recht op een eerlijk proces voor de opgeëiste persoon aan te nemen, ook al geven diens persoonlijke situatie, de aard van de strafbare feiten waarvoor hij wordt vervolgd en de feitelijke context van de uitvaardiging van het aanhoudingsbevel geen aanleiding om te veronderstellen dat de uitvoerende of wetgevende macht druk zou uitoefenen op de rechterlijke instanties van de uitvaardigende lidstaat om het strafproces tegen deze persoon te beïnloeden? Volgens de rechtbank moet deze vraag eveneens bevestigend worden beantwoord. Daarbij merkt de rechtbank ten slotte voor de volledigheid op dat de opgeëiste persoon los van die structurele en fundamentele gebreken, geen specifieke zorgen heeft geuit en dat zijn persoon noch de aard van de strafbare feiten [PV: in casu drugsdelicten] aanleiding geeft voor vrees voor concrete druk op of beinvloeding van diens strafproces door de uitvoerende of wetgevende macht.

Over het antwoord op de tweede en derde prejudiciële vraag is het Hof van Justitie duidelijk. Er is geen reden om af te zien van de tweestappentoetsing, die zich richt op het bepalen van het reële gevaar in de concrete zaak. De negatieve ontwikkelingen die de rechtbank schetst met betrekking tot de onafhankelijkheid van de rechtspraak in Polen geven volgens het Hof van Justitie aanleiding voor de rechter om extra waakzaam te zijn of in de individuele strafzaak waarop het EAB is gebaseerd, een risico van schending van het recht op een eerlijk proces van de opgeëiste persoon speelt. ${ }^{34}$

Het Hof van Justitie herhaalt ook een passage uit het $L M$-arrest: uit overweging 10 van het kaderbesluit $\mathrm{EAB}$ volgt dat de toepassing van het kaderbesluit (in alle zaken) slechts kan worden opgeschort indien een voortdurende en ernstige schending van fundamentele rechten leidt tot inzet van het Rule of Law-mechanisme en dat tot sancties leidt (art. 7 lid 2 VEU). Daarvoor is dan vervolgens tevens nog een aparte beslissing van de Raad vereist om het kaderbesluit $\mathrm{EAB}$ in te trekken. ${ }^{35} \mathrm{Zou}$ worden aanvaard dat structurele of fundamentele gebreken met betrekking tot de onafhankelijkheid van de rechterlijke macht van de uitvaardigende lidstaat in algemene zin als toetsingscriterium gelden, dan zou dit - in strijd met de genoemde bepaling - leiden tot een feitelijke opschorting van de uitvoering van de regeling van het EAB ten aanzien van diezelfde lidstaat. ${ }^{36}$ Deze precisering van het Hof van Justitie dat het gaat om twee achtereenvolgende stappen is denk ik niet zonder belang. Het is denkbaar dat het Rule of Law-mechanis- me leidt tot sancties tegen een lidstaat, op een wezenlijk onderdeel van de democratische rechtsstaat (bijvoorbeeld stemrecht of persvrijheid), dat echter geen betrekking heeft op het strafrecht en derhalve niet behoeft te leiden tot opschorting van het kaderbesluit EAB.

Het komt dus aan op de tweede stap van de toetsing: het onderzoek naar de vraag of in deze concrete zaak, gelet op de persoon, de feiten en de context van het EAB, een reëel gevaar van een schending van het recht op een eerlijk proces dreigt. Het Hof van Justitie geeft een klein voorbeeld van relevante omstandigheden: 'zoals verklaringen van overheidsinstanties die de behandeling van een individueel geval kunnen beïnloeden'. Indien sprake is van én algemene informatie die wijst op structurele gebreken aan de onafhankelijkheid van de rechtspraak, én zwaarwegende en op feiten berustende gronden om aan te nemen dat een persoon een reëel gevaar loopt dat zijn recht op een eerlijk proces wordt geschonden, moet de uitvoerende rechterlijke autoriteit uitvoering van het $\mathrm{EAB}$ weigeren. Als dat niet het geval is, moet hij dat juist uitvoeren (art. 1 lid 2 kaderbesluit EAB). ${ }^{37}$

Het Hof van Justitie voegt nog toe dat het kaderbesluit Europees aanhoudingsbevel in het bijzonder als doel heeft om te voorkomen dat daders van strafbare feiten door te vluchten naar een andere lidstaat kunnen ontkomen aan bestraffing. Ook die doelstelling verzet zich tegen het loslaten van de tweestappentoetsing. ${ }^{38}$

Ten slotte gaat het Hof van Justitie in op het verschil in toetsing in geval van een EAB dat strekt tot vervolgingsoverlevering en een $\mathrm{EAB}$ dat ziet op executieoverlevering. Bij een $\mathrm{EAB}$ dat strekt tot vervolgingsoverlevering draait het erom dat de uitvoerende rechter zich focust op de vraag of de opgeëiste persoon een eerlijk proces zal krijgen. In het geval van een executie-EAB moet de rechter bepalen of de straf die de opgeëiste persoon na overlevering moet uitzitten het resultaat is van een veroordeling die tot stand is gekomen naar aanleiding van een eerlijk proces. ${ }^{39}$

\section{De uitspraak in bredere perspectief van voorkomen mensenrechtenschendingen in overleverings- en
uitleveringszaken}

Het is de taak van de rechter in overleveringszaken om actief te waken voor eventuele schending van de fundamentele rechten van de opgeëiste persoon. Dat vereist een rechter die een brede blik heeft op de zaak en verder kijkt dan enkel hetgeen zwart op wit in de formele stukken te vinden is. Daarvan toont de recht-

\footnotetext{
34. L. en $P$., punt $53-56,60$

35. L. en $P$., punt 57-58.

36. L. en $P$., punt 59 .
}

37. L. en P., punt 61.
38. L. en P., punt 62-64.
39. L. en P., punt 66-68. 
bank Amsterdam zich, met enkele andere rechters (een Ierse rechter en een aantal Duitse rechters), een goed voorbeeld. De genoemde rechters menen - die gedachte ligt ten grondslag aan hun prejudiciële vragen en (tussen)beslissingen in overleveringszaken ${ }^{40}$ - dat de situatie waarin de Poolse rechtspraak verkeert dermate ernstig is dat het recht op een eerlijk proces van een opgeëiste persoon die zou worden overgeleverd aan Polen in gevaar komt. Ik schat zo in dat het Hof van Justitie met het arrest van 17 december 2020 niet alle vragen heeft weggenomen die de situatie in Polen bij hen zou kunnen oproepen in het kader van de mensenrechtentoetsing in overleveringszaken. Bijvoorbeeld: houdt het Hof van Justitie bij overlevering wellicht te streng (strenger bijvoorbeeld dan het EHRM) vast aan een beoordeling van de feiten en omstandigheden strikt in het individuele geval? Moet de - door het Hof van Justitie in ander verband immers ook vastgestelde - aantasting van de rechterlijke onafhankelijkheid in Polen niet tot de conclusie leiden dat verdachten die worden overgeleverd aan Polen geen eerlijk proces door een onafhankelijke rechter te wachten staat: is er met andere woorden wellicht sprake van een innerlijke tegenstrijdigheid in de rechtspraak van het Hof van Justitie?

Er zijn verschillende invalshoeken van waaruit die vragen zouden kunnen worden beantwoord. Aandacht verdienen mijns inziens in ieder geval de volgende invalshoeken: (1) de inhoud van het recht op een onafhankelijke rechter en (2) de werking van de mensenrechtenexceptie in uitleverings- en overleveringszaken in dat verband. Die invalshoeken zal ik kort analyseren met behulp van de uitgebreidere rechtspraak van het EHRM over artikel 6 lid 1 EVRM. Die bepaling is het equivalent in het EVRM van artikel 47, tweede alinea, Handvest. ${ }^{41}$ De rechtspraak van het EHRM kan in dit verband als een soort spiegel dienen voor de rechtspraak van het Hof van Justitie.

In de rechtspraak van het EHRM over het recht op een onafhankelijke rechter op grond van artikel 6 lid 1 EVRM komen concrete aspecten van die onafhankelijkheid naar voren. ${ }^{42}$ Het gaat in het bijzonder om de onafhankelijkheid van de rechter ten opzichte van de uitvoerende macht en van de partijen in de zaak. Voorts meer specifiek om aspecten als de wijze van benoeming, de duur van de aanstelling, het bestaan van waarborgen tegen externe druk, en de vraag of het betrokken rechterlijke orgaan een indruk van onafhankelijkheid geeft. ${ }^{43}$ Het EHRM oordeelde dat benoeming van rechters door de uitvoerende macht of door het parlement geen aantasting van de onafhankelijkheid vormt, als er voldoende waarborgen voor onafhankelijkheid in de procedure zijn

40. Zie o.a. OLG Karlsruhe 17 februari 2020, Ausl. 301 AR 156/19.

41. In het EU-recht wordt de onafhankelijkheid van de rechtspraak vereist door art. 19 VEU.

42. Zie D.J. Harris, M. O'Boyle, E.P. Bates \& C.M. Buckley, Law of the European Convention on Human Rights, Oxford: Oxford University Press 2018, p. 448-458 en ECHR, Factsheet - Independence of the justice system, april 2021.

43. EHRM 18 juli 2013, appl.nrs. 2312/08 en 34179/08 (Maktouf en Damjanovic/Bosnië Herzegovina). opgenomen (bijvoorbeeld voorafgaande selectie door een onafhankelijk orgaan). ${ }^{44}$ Bij het EHRM is onder andere een zaak aanhangig waarin de wijze van benoeming van leden van het Poolse Hooggerechtshof aan de kaak wordt gesteld. ${ }^{45}$ Een volgende categorie gaat over disciplinaire procedures waarin sancties kunnen worden opgelegd aan rechters. In de zaak Oleksandr Volkov/ Oekraïne bepaalde het EHRM dat een disciplinaire kamer voor de rechtspraak als niet-onafhankelijke rechter moest worden aangemerkt, onder andere omdat de overgrote meerderheid van de leden afkomstig was van buiten de rechtspraak en was benoemd door de uitvoerende macht en het parlement. ${ }^{46}$ In aansluiting hierop zijn er zaken waarin een schending van artikel 6 lid 1 EVRM werd aangenomen omdat werd getornd aan garanties voor onafhankelijkheid van rechters, zoals beëindiging van een functie voor de wettelijk bepaalde termijn of gedwongen overplaatsing. Over soortgelijke situaties zijn verschillende zaken van Poolse rechters aanhangig bij het EHRM. ${ }^{47}$ Ten slotte kan een categorie worden onderscheiden van uitlatingen van de uitvoerende macht over rechters en lopende rechtszaken die een schending van het recht op een onafhankelijke rechter kunnen opleveren. ${ }^{48}$

Tot op heden zijn schendingen van artikel 6 lid 1 EVRM inzake het recht op een onafhankelijke rechter aangenomen ten aanzien van de positie van individuele rechters en bepaalde rechterlijke colleges. Het is echter nog niet zo ver gekomen dat het EHRM vervolgens heeft vastgesteld dat de gehele (straf)rechtspraak in een staat niet langer als onafhankelijk kan worden aangemerkt.

Is het voorstelbaar dat het in het geval van Polen ooit zover komt? Misschien wel. Duidelijk is in ieder geval dat daarvoor een sterke onderbouwing nodig zal zijn. Die zou moeten aantonen dat het geheel aan maatregelen die de uitvoerende macht in Polen heeft genomen in het kader van 'hervorming van de rechtspraak', in het bijzonder resulterend in de dreiging van disciplinaire procedures voor de Tuchtkamer - ertoe leidt dat Poolse rechters in om het even welke zaak die zij krijgen voorgelegd, niet meer op onafhankelijke en onpartijdige wijze recht kunnen spreken. Dat er sprake is van een chilling effect. De onderbouwing zou gebaat zijn bij voorbeelden van zaken waarin dit gelet op politiek gevoelige onderwerpen duidelijk aan de orde is en die de 'objectief gerechtvaardigde twijfel opleveren over de onafhankelijkheid' van de rechter; een criterium dat het EHRM gebruikt bij bepaling of er sprake is van een schending.

44. Maktouf en Damjanovic/Bosnië Herzegovina.

45. Zaak Reczkowicz e.a./Polen (appl.nrs. 43447/19, 49868/19 en 57511/19)

46. EHRM 9 januari 2013, appl.nr. 21722/11 (Oleksandr Volkov/Oekraïne).

47. De zaken Grzeda/Polen (appl.nr. 43572/18), Broda/Polen en Bojara/ Polen (appl.nrs. 26691/18 en 27367/18), Zurek/Polen (appl.nr. 39650/18).

48. Zie o.a. EHRM 27 januari 2015, appl.nr. 37124/10 (Toni Kostadinov/ Bulgarije). 
Als dat het geval is - hetgeen nu nog niet de situatie is dan zou moeten worden geconcludeerd dat een persoon die aan Polen wordt overgeleverd geen eerlijk proces bij een onafhankelijke rechter te wachten staat. Het zou tevens inhouden, en dat is nog veel ingrijpender, dat geen enkele verdachte die in Polen voor de strafrechter wordt gebracht, een eerlijk proces krijgt. De verstrekkende gevolgen van een dergelijke vaststelling lijken sterk te pleiten voor een beoordeling door het EHRM of het Hof van Justitie, en niet door een rechter van een (andere) lidstaat.

Concluderend kan de eerste invalshoek van (A) vaststelling van een schending van het recht op een onafhankelijke rechter, via (B) een veralgemenisering van dat oordeel ten aanzien van de gehele (straf)rechtspraak, ertoe leiden dat (C) er noodzakelijkerwijs ook consequenties zijn voor het individuele geval van een aan de desbetreffende lidstaat over te leveren persoon. Die derde stap $\mathrm{C}$ behoeft dan geen nadere toetsing meer van een reëel gevaar van blootstelling aan schending van het recht op een eerlijk proces in het concrete geval. Zo zou ik de redenering die ten grondslag ligt aan de tweede en derde vraag van de rechtbank Amsterdam in het besproken arrest willen uitleggen. Het gaat echter om verschillende opeenvolgende stappen, in verschillende domeinen. De rechtspraak van het Hof van Justitie in de inbreukprocedures en naar aanleiding van de prejudiciële vragen gesteld door Poolse rechters over aantastingen van de rechterlijke onafhankelijkheid situeert zich in stap A. Hetzelfde geldt denk ik voor de grieven waarvoor het Rule of Law-mechanisme in gang is gezet. Zonder invulling van stap B - voorlopig de missing link komt de rechter bij een toetsing niet bij stap C. Er is mijns inziens dan ook geen sprake van innerlijke tegenstrijdigheid in de rechtspraak van het Hof van Justitie.

De tweede invalshoek is die van de mensenrechtenexceptie in relatie tot het recht op een eerlijk proces (als het ware andersom, direct bij stap C) beginnen). Dat is de weg die het Hof van Justitie voorschrijft in het besproken arrest.

Het criterium dat het EHRM hieromtrent hanteert, is dat van een 'dreigende flagrante schending van mensenrechten'. Uitgangspunt is dat partijen bij het EVRM er onderling op moeten vertrouwen dat zij de fundamentele rechten gewaarborgd door het EVRM respecteren. Onderzoek is echter nodig indien daarover gerede twijfel bestaat, naar aanleiding van een verweer van de betrokkene dat zijn fundamentele rechten dreigen te worden geschonden door uitlevering. De betrokkene dient daartoe bewijs ter onderbouwing aan te leveren. Het gaat daarbij vaak mede om rapporten van internationale organisaties of uitspraken van rechterlijke instanties. Dan moet de rechter onderzoeken - als tweede stap - of in de individuele zaak de opgeëiste persoon het reële risico loopt te worden blootgesteld aan een flagrante mensenrechtenschending. $\mathrm{Bij}$ een flagrante schending in relatie tot artikel $6 \mathrm{EVRM}$ - flagrant denial of justice - gaat het, zoals het EHRM heeft bepaald in de zaak Othman/Verenigd Koninkrijk, niet om een nauwkeurig bepaald begrip.
'A flagrant denial of justice goes beyond mere irregularities or lack of safeguards in the trial procedures such as might result in a breach of Article 6 if occurring within the Contracting State itself. What is required is a breach of the principles of fair trial guaranteed by Article 6 which is so fundamental as to amount to a nullification, or destruction of the very essence, of the right guaranteed by that Article.'49

Voorbeelden daarvan zijn volgens het EHRM een verstekveroordeling zonder rechtsmiddel, geen verdedigingsrechten tijdens het proces, detentie zonder toetsing door een onafhankelijke rechter, structureel geen bijstand door een raadsman ${ }^{50}$ en het gebruik van bewijs dat is verkregen door foltering. ${ }^{51}$ Aannemelijk acht ik dat voorts een aantal zaken waarin het EHRM een dreigende schending van artikel 3 EVRM heeft vastgesteld, mutatis mutandis ook tot een dreigende flagrante schending van het recht op een eerlijk proces kan leiden: bijvoorbeeld ferme uitlatingen van de uitvoerende macht over de zaak, waaruit de vrees kan ontstaan dat er geen eerlijk proces plaatsvindt. ${ }^{52}$ Ten slotte moet het zo zijn dat de schending niet alleen niet kan worden voorkomen, bijvoorbeeld door garanties ter waarborging van een eerlijk proces te verlangen en te verkrijgen, maar ook dat er geen remedie tegen is in de zin van een adequaat rechtsmiddel als bedoeld in artikel 13 EVRM.

Concluderend over de tweede invalshoek gaat het EHRM evenals het Hof van Justitie uit van een tweestappentoetsing bij een mogelijk dreigende schending van mensenrechten van een opgeëiste persoon. Het lijkt op het eerste gezicht niet zo te zijn dat de toetsing van het Hof van Justitie in dit verband strenger is dan die van het EHRM. Stringentere toetsing op EU-vlak zou misschien kunnen worden verwacht op grond van het verplichtende karakter van het beginsel van wederzijdse erkenning dat het kaderbesluit EAB draagt. Maar het EHRM beschouwt het geven van extraterritoriale werking aan het waarborgen van het recht op een eerlijk proces als uitzonderlijk: een interventie in de rechtsorde van een andere (lid)staat dient voorbehouden te blijven voor de urgentste en ernstigste gevallen. Als ik de diepere redenen voor die terughoudendheid zou moeten duiden, zou ik die zoeken in het belang dat in de internationale rechtsorde is gemoeid met de zorgvuldigheid, de legitimiteit en de integriteit van de toepassing van de mensenrechtenexceptie. Daarmee wordt gegarandeerd dat de mensenrechtenexceptie duurzaam haar belangrijke rol kan blijven spelen.

De focus op de feiten en omstandigheden in een individuele zaak behoeft niet te betekenen dat de aantasting van de onafhankelijkheid van de rechtspraak in Polen niet op enig moment ertoe zal leiden dat in een

\footnotetext{
49. Zie EHRM 17 januari 2012, appl.nr. 8139/09 (Othman (Abu Qatada)/ $V K)$, punt 260.

50. Zie Othman (Abu Qatada)/VK, punt 259.

51. EHRM 24 juli 2014, appl.nr. 28761/11 (Al Nashiri/Polen). 52. EHRM 1 april 2010, appl.nr. 24268/08 (Klein/Rusland).
} 
individuele zaak het reële gevaar van een schending wordt aangenomen. Vanuit beide besproken invalshoeken is een scenario voorstelbaar, waarin de antasting van de rechterlijke onafhankelijkheid in Polen toch tot een weigering van overlevering moet leiden wegens een reëel gevaar van blootstelling aan een schending van fundamentele rechten.

Het scenario bij de eerste invalshoek is dat van escalatie van maatregelen tegen Poolse rechters en het als gevolg hiervan duidelijk intreden van een chilling effect in de gehele Poolse rechtspraak. Het scenario dat zich bij de tweede invalshoek zou kunnen voordoen is dat van specifieke omstandigheden in de zaak van een opgeëiste persoon voor wiens overlevering een Pools EAB is uitgevaardigd, waardoor de aantastingen van de onafhankelijkheid van de Poolse rechtspraak juist in zijn zaak een grote kans op schending van het recht op een eerlijk proces opleveren. Dat kan bijvoorbeeld het geval zijn als het gaat om een zaak die qua inhoud de kern van het conflict tussen regering en rechtspraak raakt (bijvoorbeeld de doorwerking van uitspraken van het Hof van Justitie), of die uitlatingen of anderszins negatieve aandacht uitlokt van de uitvoerende macht waardoor extra druk ontstaat op de onafhankelijkheid van de rechters in de zaak. Dit is wat het Hof van Justitie mijns inziens ook lijkt te suggereren in het besproken arrest van 17 december 2020.

\section{Epiloog}

$\mathrm{Na}$ de uitspraak van het Hof van Justitie heeft de rechtbank Amsterdam de beslissing genomen om in een aantal zaken waarin de behandeling van Poolse EAB's was opgeschort in afwachting van het arrest van het Hof van Justitie, de overlevering van opgeëiste personen aan Polen toch toe te staan. Het ging voornamelijk om executieoverlevering, zaken waarin de opgeëiste persoon al was berecht in Polen.

In één zaak heeft de rechtbank de overlevering aan Polen geweigerd wegens het reële gevaar van een schending van het recht op een eerlijk proces. Het gaat om een van de zaken waarin prejudiciële vragen zijn gesteld ${ }^{53}$ De rechtbank stelt dat door de procedure bij het Hof van Justitie de opgeëiste persoon op negatieve wijze in beeld is gekomen bij de Poolse autoriteiten. Bovendien hebben de Poolse autoriteiten naar anleiding van deze zaak aangestuurd op weigering van Nederlandse EAB's. Verder legt de rechtbank een verband tussen het feit dat de opgeëiste persoon zal worden berecht in Poznan en het feit dat tegen twee rechters van die rechtbank (om andere redenen) een tuchtprocedure loopt. Dat zou een chilling effect kunnen hebben op de onafhankelijkheid van (andere) rechters in die rechtbank bij de berechting van de opgeëiste persoon aldaar. Tot slot gebruikt de rechtbank als argument dat de vragen

53. Rb. Amsterdam 10 februari 2021, ECLI:NL:RBAMS:2021:420 over de Tuchtkamer niet zijn beantwoord. De optelsom vindt de rechtbank voldoende om de uitvoering van het EAB te weigeren.

Uit deze onderbouwing wordt duidelijk dat de rechtbank de twee scenario's die hierboven zijn besproken waarin een weigering van de overlevering op grond van een reëel gevaar op schending van het recht op een eerlijk proces zou kunnen zijn aangewezen, helder voor ogen heeft. Ze worden in combinatie gebruikt, waarbij doorslaggevend toch het tweede scenario is van de specifieke omstandigheden in de zaak van de opgeëiste persoon. De door het Hof van Justitie in het arrest van 17 december 2020 voorgeschreven focus op de omstandigheden in de individuele zaak leidt op deze manier toch nog snel tot een daadwerkelijke weigering in een overleveringszaak. ${ }^{54}$
54. In een andere zaak heeft de rechtbank Amsterdam besloten nader onderzoek in te stellen op grond van het verweer van de verdediging van de opgeëiste persoon dat die in Polen zal worden berecht door een rechtbank en een gerechtshof waarvan leden tevens zitting hebben in de regeringsgezinde raad voor de rechtspraak (Rb. Amsterdam 13 april 2021, ECLI:NL:RBAMS:2021:1865). 